Pak. J. Agri., Agril. Engg., Vet. Sci., 2020, 36 (2): 101-105

ISSN: 1023-1072 (Print), ISSN: 2663-7863 (Online)

https://doi.org/10.47432/2020.36.2.3

\title{
FREE RADICAL SCAVENGING POTENCY OF FIVE DATE PALM (PHOENIX DACTYLIFERA L.) FRUIT VARIETIES CULTIVATED IN KHAIRPUR MIR'S
}

\author{
Z. A. Mahar ${ }^{* 1}$, G. Q. Shar ${ }^{1}$ and A. R. Shaikh ${ }^{1}$ \\ ${ }^{1}$ Institute of Chemistry, Shah Abdul Latif University, Khairpur Mir's, Pakistan
}

\begin{abstract}
The fruit of date palm (Phoenix dactylifera L.) is well-known for its several health blessings and dietary values and its wonderful supply of phenolics compounds and holds relatively exquisite antioxidant capacity. Therefore, the goal of this study is to investigate the free radical scavenging efficiency of the five-date types Aseel, Kupro, Karbala Wari, Asul Khurmo and Gajar Wari cultivated in district Khairpur Mir's. These date varieties were screened with the help of DPPH assay to evaluate their free radical scavenging efficiency in different solvents. From the statistics, it turned into scrutinize that each extract has interesting antioxidant functionality against free radicals. The methanolic extract has more potential to incline the free radicals. It was concluded that the date variety Asul Khumro is shown excellent activity because it possesses lowest IC I0 $_{50}$ value $17.823 \mu \mathrm{g} / \mathrm{mL}$, followed by Gajar Wari $20.679 \mu \mathrm{g} / \mathrm{mL}$ in methanolic solution while Kupro $20.937 \mu \mathrm{g} / \mathrm{mL}$ in Methanol + Water solution then relaxation of different date varieties at their mature Tamar level. It is concluded from the results that all dates fruit varieties at their final mature stage holds higher antioxidant potency and indicated that these date fruits have natural antioxidants.
\end{abstract}

Keywords: antioxidants, DPPH, date fruit, methanol, water

\section{INTRODUCTION}

The fruit of date palms is extremely healthy; because it possesses sugar in the form of sucrose, glucose and fructose (Al-Shahib and Marshall, 2003) and it is excellent source of dietary fiber and necessary vitamins and minerals. Additionally, date palms have been reported to hold a range of polyphenols, containing hydroxycinnamates, phenolic acids, proanthocyanidins and flavonoid glycosides that made it an attractive fruit from medicinal and a pharmaceutical point of view. Literature revealed that phenolic compounds are a main supply of natural antioxidants in foods of plant origin (Cartea, et al., 2011) and show a broad range of biochemical behavior like anticarcinogenic, antimutagenic and antimicrobial. Various studies verify important association among the high dietary intake of flavonoids and the decrease the cardiovascular and carcinogenic risks.

The species that can neutralize free radical by donating an electron and reducing its ability to harm essential molecules are called antioxidants (Devasagayam et al., 2004; Tan et al., 2002; Valko, 2006). Antioxidant plays a

\footnotetext{
“Corresponding author: azaheer1568@gmail.com
}

critical function in human health consequently it receives greater significance in the medical discipline as well as in the area of food sciences (Lobo, et al., 2010). Essential bioactive molecules containing DNA and protein can be damaged by free radicals and causes the several cardiovascular and chronic disease (Halliwell and Gutteridge, 1985; Liao and Yin, 2000; Pham-Huy, He, and Phamy et al., 2008). Even as the human body protects them by using antioxidant nutrients and enzymes that capture dangerous property of ROS. Consistent combining the chemicals and pollutants could enhance the attention of reactive oxygen species in the body at the back of its capability to keep such things, causing irreversible oxidative damage. For this reason, antioxidants could have been essential for inhibiting and recovering the disorder in which unfastened radicals are involved (Tiwari, 2001; Valko et al., 2007). Vegetables, fruits and plants supply polyphenolic compounds consisting of flavonoids and phenolic acids (Balasundram, et al., 2006) which are called the herbal antioxidants, which have a lot of biological results as well as contain the capability to reduce the danger of disease.The date fruit have lots of vital minerals (Al-Shahib and Marshall, 
2003). It moreover has proteins and amino acids within better care than various fruits (Al-Shahib and Marshall, 2003; Vayalil, 2002). In addition to its dietary worth, dates are packed with the phenolic compounds due to the potential of antioxidants against free radicals (Sirry and Babiker, 2017; Zheng and Wang, 2001). It's far pronounced from literature that Alligue (date variety) possess the lowest EC50 Value 0.62 $\mathrm{mg} / \mathrm{ml}$ followed via Deglet Nour $(1.53 \mathrm{mg} / \mathrm{ml}$ ), Kentichi $(1.68 \mathrm{mg} / \mathrm{ml})$ and khouet Kenta $(1.96$ $\mathrm{mg} / \mathrm{ml}$ ) cultivated in Tunisian through the DPPH method (Saafi, et al., 2009). The capability of the methanolic extract of those dates to scavenge Free radicals (ABTS stands for 2,2'-azino-bis (3ethylbenzothiazoline-6-sulfonic acid and DPPH stands for 1,1-Diphenyl-2-picryl-hydrazyl) may be attributed to the presence of two principal types of antioxidant compounds (Saafi et al., 2009). It is evident from the report of Ahmed (-) that the date varieties, the EC50 (half maximal effective concentration) values of Saudi Arabia date sorts turned into screened via DPPH assay and the result indicates that Ajwa variety suggests lowest EC50 value $2.90 \mathrm{mg} / \mathrm{ml}$ accompanied with the aid of Sukkari $4.30 \mathrm{mg} / \mathrm{ml}$ and Khalas $6.60 \mathrm{mg} / \mathrm{ml}$ in water extract and in alcoholic solution additionally Ajwa $3.80 \mathrm{mg} / \mathrm{ml}$ possess lowest EC50 value then Sukkari 4.10 $\mathrm{mg} / \mathrm{ml}$ and Khalas $9.10 \mathrm{mg} / \mathrm{ml}$, the decrease the EC50, the higher the antioxidant capacity (Saleh, et al., 2011).

The DPPH(1,1-Diphenyl-2-picryl-hydrazyl) test system, a very simple and clean technique based on the decrease of DPPH, a stable free radical, was completed with free radical rummaging efficiency (Mensor et al., 2001; Molyneux, 2004), because of the wide variety of odd number of electrons, DPPH Free radical generate excessive absorption at five hundred seventeen nanometers (517 nm) (Ak and Gülçin, 2008). The molecular structure of DPPH is given figure 1. At the present antioxidants could interrelate through 1, 1-diphenyl-2-picrylhydrazyl and free radical have been paired in the presence of a hydrogen donor and exchange to $\mathrm{DPPH}-\mathrm{H}$ and as the importance the absorbance's decrease from the DPPH. The creation of the DPPH-H by the radicals result of de-colorization of colour it is really related thru the number of electrons catches (Gülçin, et al., 2010). Decreasing potential is based on decolorization. In this method, assessment is being identified best for evaluating oxidants rummaging ability to some extent of new prescription, despite the fact that the DPPH option to be mixed with that of a substance that may be capable of contributing hydrogen atom, by this method it endorses to the decrease from non-radical (diphenylpicryl hydrazine) by means of the dropping the lilac color (Mello, et al., 2006). From the outcomes, it turned into stated that fruit of this plant have antioxidant possessions. The intention of this work is to know the antioxidant potency of 5 date palm fruits extracts at their mature (Tamar an Arabic word to show the mature or ripped level of dates) level with water, methanol, and the mixture of water: methanol (50:50) in step with the technique described by using Blois (1958).

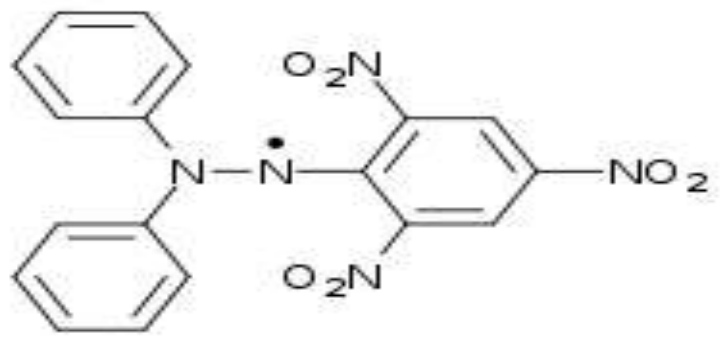

Figure 1. 1,1-Diphenyl-2-picryl-hydrazyl (DPPH)

The general mechanism of disappearance of DPPH free radicals is given as follows.

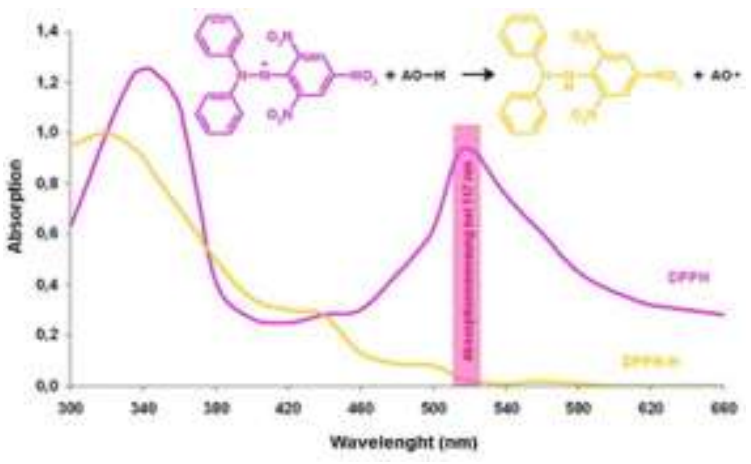

\section{MATERIALS AND METHODS}

\section{Plant material}

Five kind of date palm included Aseel, Kupro, Karbala Wari, Asul Khurmo, and Gajar Wari were collected from district Khairpur Mir's, Sindh in the summer season. These dates were identified with the help of cultivators, followed by confirmed by botanist. Samples were randomly accrued at their edible ripening time (Tamar). Three replicates of each were packed in polyethylene bags for the duration of 2 hours without any chemical treatment, subsequently, samples were transported to the laboratory for chemical evaluation. 


\section{Extract preparation}

The dates were dried under shade and ground into powder. For the extraction of dates, $(0.25 \mathrm{~g}$ of date powder was mixed with $25 \mathrm{ml}$ of $50 \%$ methanol, methanol (absolute) and water. The solutions were mixed by magnetic stirrer to half an hour and filtered by using the Whatman no.1 filter paper.

\section{The preparation of DPPH solution}

The stock solution of DPPH was prepared in methanol at a concentration of $0.1 \mathrm{mg} / 100 \mathrm{ml}$, to avoid the oxidation the solutions were stored in dark place and covered with aluminum foil (Amarowicz, et al., 2005).Fresh stock solution of DPPH was prepared for every day. To check the stability of radicals the absorbance was checked.

\section{DPPH Assay}

The DPPH radical-scavenging potency of the extracts were tested according to the technique described by Blois (1958) with some modifications. Briefly, $1 \mathrm{ml}$ of the extracts of were mixed with $1 \mathrm{ml}$ of freshly prepared DPPH solution. A $1 \mathrm{ml}$ of various solvents were mixed with DPPH solution and used as a blank solution. These solutions were incubated at room temperature for 30 minutes in dark place... After incubation, the absorbance was measured at $517 \mathrm{~nm}$ by using the spectrophotometer (UVvis Shimadzu) and transformed into the percentage unfastened radical scavenging pastime and interpreted as \% scavenged. Inhibitory concentration $\left(\mathrm{IC}_{50}\right)$ value (concentration of sample in which absorbance of DPPH decreases $50 \%$ with respect to the absorbance of the control) of extracts was calculated (Cory and McKnight, 2005; Koleva, et al., 2002). Ascorbic acid was used as a popular standard solution. The 3 replicates of each sample were analysed for DPPH radicalscavenging potency.

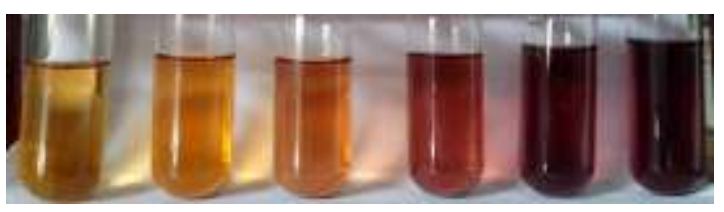

From mean value of three readings, the percent inhibition can be calculated by using the following formula:

Scavenging activity $\frac{A s-A o}{A o} \times 100$
Where, As stands for pattern absorbance and Ao stands for the absorbance of the blank.

\section{RESULTS AND DISCUSSION}

It can be observed from Table 1 that $I_{50}$ value of all 5 dates fruit varieties at their mature Tamar phase showed impressive antioxidant potency free radical potency, where date variety Kupro shows 2.937, 28.064 and 23.666; Aseel showed 23.316, 23.202 and 22.788; Asul Khumro possessed 25.059, 27.155 and 17.832; Gajar Wari had 27.211, 21.058 and 20.679, even as the variety Karbala Wari 22.493, 24.926 and $23.394 \mu \mathrm{g} / \mathrm{mL}$ in methanol, methanol: water (50:50) and water, respectively at their safe to edible repining stage.

Table1. The relative free radical potency of five date varieties

\begin{tabular}{|l|l|l|l|}
\hline Variety & Methanol:Water & Water & Methanol \\
\hline Kupro & 20.937 & 28.064 & 23.666 \\
\hline Aseel & 23.316 & 23.202 & 22.788 \\
\hline Asul khurmo & 25.059 & 27.155 & 17.823 \\
\hline Gajar wari & 27.211 & 21.058 & 20.679 \\
\hline Karbala wari & 22.493 & 24.926 & 23.394 \\
\hline \multicolumn{2}{|l}{} \\
Note: (IC-50 value in $\mathrm{gg} / \mathrm{mL})$
\end{tabular}

Using lower concentration, the $\mathrm{IC}_{50}$ (The half maximal inhibitory concentration) value was to be gained less and extra capacity to ramp the free radical in opposition to oxidants

With accordance of experimental look at via improving the quantity of extract, lower the absorption higher will be the percent inhibition. Massive absorption indicates the better variety of free radical 1, 1-diphenyl-2-picrylhydrazyl molecules (Ferreira, et al., 2007; Molyneux, 2004), something reduced absorbance demonstrated mixture of free of charge DPPH molecules through the quantity of sample. By using the lesser concentration, the value of $\mathrm{IC}_{50}$ value becomes to be achieving a smaller amount and more capability to catch the free radical in opposition to oxidants (Hussain, et al., 2008; Soobrattee, et al., 2005).

\section{CONCLUSION}

The findings of this study indicated that, all 5 date varieties at their final mature stage holds higher anti-oxidative potential however the variety of date fruit namely Asul khumro contains smaller $\mathrm{IC}_{50}$ value in methanol solvent that is $17.823 \mu \mathrm{g} / \mathrm{ml}$ as contrasts to other date palm varieties and feature the remarkable antioxidant capability to incline oxidants. While the Kupro acquires minimum $\mathrm{IC}_{50}$ value $28.064 \mu \mathrm{g} / \mathrm{ml}$ in 
water solvent at its fully ripened Tamar level and have lower antioxidant potential.

\section{ACKNOWLEDGMENT}

The research work presented in this paper was carried out in the Institute of Chemistry, Shah Abdul Latif University Khairpur Mir's, Sindh. The authors cordially acknowledged and appreciations for the provision of technical facilities.

\section{AUTHOR'S CONTRIBUTION}

Z. A. Mahar: Manuscript writeup and laboratory work

G. Q. Shar: Provided technical support

A. R. Shaikh: Helped in sample collections

\section{REFERENCES}

Ak, T. and I. Gülçin. 2008. Antioxidant and radical scavenging properties of curcumin. Chemico-biological interactions, 174 (1): 27-37.

Al-Shahib, W. and R. J. Marshall. 2003. The fruit of the date palm: it's possible use as the best food for the future? International Journal of Food Sciences and Nutrition, 54 (4): 247-259.

Amarowicz, R., A. Troszyńska and F. Shahidi. 2005. Antioxidant activity of almond seed extract and its fractions. Journal of Food Lipids, 12 (4): 344-358.

Balasundram, N., K. Sundram and S. Samman. 2006. Phenolic compounds in plants and agri-industrial by-products: Antioxidant activity, occurrence, and potential uses. Food chemistry, 99 (1): 191-203.

BLOIS, M. S. 1958. Antioxidant Determinations by the Use of a Stable Free Radical. Nature 181:1199-1200.

Cartea, M. E., M. Francisco, P. Soengas and P. Velasco. 2011. Phenolic compounds in Brassica vegetables. Molecules, 16 (1): 251280.

Cory, R. M. and D. M. McKnight. 2005. Fluorescence spectroscopy reveals ubiquitous presence of oxidized and reduced quinones in dissolved organic matter. Environmental Science and Technology, 39 (21): 8142-8149.

Devasagayam, T., J. Tilak, K. Boloor, K. S. Sane, S. S. Ghaskadbi and R. Lele. 2004. Free radicals and antioxidants in human health: Current Status and Future Prospects. Japi, 52: 794-804.

Ferreira, I. C., P. Baptista, M. Vilas-Boas and L. Barros. 2007. Free-radical scavenging capacity and reducing power of wild edible mushrooms from northeast Portugal: Individual cap and stipe activity. Food Chemistry, 100 (4): 1511-1516.

Gülçin, İ., Z. Huyut, M. Elmastaş and H. Y. Aboul-Enein. 2010. Radical scavenging and antioxidant activity of tannic acid. Arabian Journal of Chemistry, 3 (1): 43-53.

Halliwell, B., J. M. Gutteridge. 1985. Free radicals in biology and medicine.

Hussain, A. I., F. Anwar, S. T. H. Sherazi and R. Przybylski. 2008. Chemical composition, antioxidant and antimicrobial activities of basil (Ocimum basilicum) essential oils depends on seasonal variations. Food Chemistry, 108 (3): 986-995.

Koleva, I. I., T. A. Van Beek, J. P. Linssen, A. D. Groot and L. N. Evstatieva. 2002. Screening of plant extracts for antioxidant activity: a comparative study on three testing methods. Phytochemical Analysis: An International Journal of Plant Chemical and Biochemical Techniques, 13 (1): 8-17.

Liao, K. I. and M. C. Yin. 2000. Individual and combined antioxidant effects of seven phenolic agents in human erythrocyte membrane ghosts and phosphatidylcholine liposome systems: importance of the partition coefficient. Journal of Agricultural and Food Chemistry, 48 (6): 2266-2270.

Lobo, V., A. Patil, A. Phatak and N. Chandra. 2010. Free radicals, antioxidants and functional foods: Impact on human health. Pharmacognosy Reviews, 4 (8): 118-126.

Mello, L. D., S. Hernandez, G. Marrazza, M. Mascini and L. T. Kubota. 2006. Investigations of the antioxidant properties of plant extracts using a DNAelectrochemical biosensor. Biosensors and Bioelectronics, 21 (7): 1374-1382.

Mensor, L. L., F. S. Menezes, G. G. Leitão, A. S. Reis, T. C. D. Santos, C. S. Coube and S. G. Leitão. 2001. Screening of Brazilian plant extracts for antioxidant activity by the use of DPPH free radical method. Phytotherapy Research, 15 (2): 127-130.

Mimica-Dukić, N., B. Božin, M. Soković, B. Mihajlović and M. Matavulj. 2003. Antimicrobial and antioxidant activities of three Mentha species essential oils. Planta Medica, 69 (05): 413-419.

Molyneux, P. 2004. The use of the stable free radical diphenylpicrylhydrazyl (DPPH) for estimating antioxidant activity. Songklanakarin Journal of Science and Technology, 26 (2): 211-219. 
Pham-Huy, L. A., H. He and C. Pham-Huy. 2008. Free radicals, antioxidants in disease and health. International journal of biomedical science: IJBS, 4 (2): 89-96.

Saafi, E. B., A. El Arem, M. Issaoui, M. Hammami and L. Achour. 2009. Phenolic content and antioxidant activity of four date palm (Phoenix dactylifera L.) fruit varieties grown in Tunisia. International Journal of Food Science and Technology, 44 (11): 2314-2319.

Saleh, E. A., M. S. Tawfik and H. M. AbuTarboush. 2011. Phenolic contents and antioxidant activity of various date palm (Phoenix dactylifera L.) fruits from Saudi Arabia. Food and Nutrition Sciences, 2 (10): 1134-1141.

Sirry, S. and H. Babiker. 2017. Comparison of free radical scavenging capacities of methanol extract of two mint species by fixed point and kinetic methods. Algerian Journal of Natural Products, 5 (3): 562-572.

Soobrattee, M. A., V. S. Neergheen, A. Luximon-Ramma, O. I. Aruoma and T. Bahorun. 2005. Phenolics as potential antioxidant therapeutic agents: mechanism and actions. Mutation Research/ Fundamental and Molecular Mechanisms of Mutagenesis, 579 (1): 200-213.

Tan, D., R. J. Reiter, L. C. Manchester, M. Yan, M. El-Sawi, R. M. Sainz and R. Hardeland.
2002. Chemical and physical properties and potential mechanisms: melatonin as a broad spectrum antioxidant and free radical scavenger. Current Topics in Medicinal Chemistry, 2 (2): 181-197.

Tiwari, A. K. 2001. Imbalance in antioxidant defence and human diseases: Multiple approach of natural antioxidants therapy. Current Science, 1179-1187.

Valko, M., C. Rhodes, J. Moncol, M. Izakovic and M. Mazur. 2006. Free radicals, metals and antioxidants in oxidative stress-induced cancer. Chemico-Biological Interactions, 160 (1): 1-40.

Valko, M., D. Leibfritz, J. Moncol, M. T. Cronin, M. Mazur and J. Telser. 2007. Free radicals and antioxidants in normal physiological functions and human disease. The International Journal of Biochemistry and Cell Biology, 39 (1): 44-84.

Vayalil, P. K. 2002. Antioxidant and antimutagenic properties of aqueous extract of date fruit (Phoenix dactylifera L. Arecaceae). Journal of Agricultural and Food Chemistry, 50 (3): 610-617.

Zheng, W. and S. Y. Wang. 2001. Antioxidant activity and phenolic compounds in selected herbs. Journal of Agricultural and Food Chemistry, 49 (11): 5165-5170.

(Received: August 04, 2020; Accepted: December 22, 2020) 